\title{
WARM REINFORCEMENT AND COLD REINFORCEMENT MAGNET SYSTEMS FOR TOKAMAK FUSION POWER REACTORS: \\ A COMPARISON*
}

\author{
J. R. Powell and P. Bezler \\ Department of Applied Science \\ Brookhaven National Laboratory \\ Upton, I.I., N.Y. 11973
}

November 1972

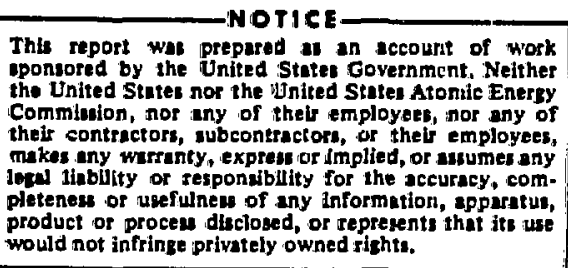

$*$

This work was supported by the U.S. Atomic Energy Commission. 
This report was prepared as an account of work sponsored by the United States Government. Neither the United States nor the United States Atomic Energy Commission, nor any of their employees, nor any of their contractors, subcontractors, or their employees, makes any warranty, express or implied, or assumes any legal liability or responsibility for the accuracy, completeness or usefulness of any information, apparatus, product or process disclosed, or represents that its use would not infringe privately owned rights. 


\section{TABLE OF CONTENTS}

Page

Abstract

Introduction

Description of Thermal Barrier

Selection of Tokamak Fusion Reactors to be 10 Compared

Stress Analysis of Magnets

Results of Analysis

Magnet Construction

Summary and Conclusions

Acknowledgment

References

Tables

Figures 
WARM REINFORCEMENT AND COLD REINFORCEMENT MAGNET SYSTEMS FOR TOKAMAK FUSION POWER REACTORS:

A COMPARISON

\author{
J. R. Powell and P. Bezler \\ Department of Applied Science \\ Brookhaven National Iaboratory \\ Upton, L.I., N.Y. 11973
}

\title{
P.BSTRACT
}

Warm reinforcement and cold reinforcement magnets are compared for a range of tokamak fusion reactor sizes and fields for $D T$ and catalyzed DD fuel cycles. In the conventional cold reinforcement methnd all magnetic forces are contained by a $4 \mathrm{~K}$ structure reinforced with stainless steel; in the warm reinforcernent method, the magnetic forces are transmitted across a low thermal conductivity structural layer to a warm $(300 \mathrm{k})$ reinforcing structure made of ordinary materials. For high-field fusion reactors, the magnets are so large that the cost of the additional refrigeration load for warm reinforcement is much less than the savings in structural costs it permits. This warm reinforcement method should permit the construction of reasonable cost $(\$ 40 / \mathrm{kW}(e))$ magnets with relatively low structural stresses for catalyzed DD reactors.

\section{INTRODUCTION}

The characteristics of large-bore, high-field magnets will be an important factor in determining the overall 
technological and economic practicality of fusion reactors based on magnetic containment of plasmas, as well as in selecting the best containment concept. In addition, if practical magnets can be built for reactors based on DD fuel cycles, the complex and difficult tritium breeding blanket necessary for DT fuel cycles can be avoided.

It seems very likely these fusion reactor magnets will be entirely (or in some cases, predominantly) superconducting in order to avoid prohibitive magnet power requirements. Occasionally, it may be desirable to use a relatively limited amount of cryogenic aluminum conductor at 10 to $20 \mathrm{~K}$ as a high-field insert for very high-field magnets, and this appears to be practical.

The cost of superconducting laboratory magnets is strongly dominated by superconductor and refrigeration cost, while structural cost is relatively minor. It appears that this situation should be reversed for the much larger magnets necessary for fusion reactors, that is, the structural cost would become predominant while superconductor and cryogenic: costs would become minor.

This is due in part to the effects of scaling factors, i.e.. the amount of superconductor and cryogenic heat leak scale as the surface area of the magnet while the amount of structural reinforcement scales as the volume, but is also 
due to the expected large reductions in unit costs for superconductors and refrigeration as their total requiroments increase. In contrast, a unit structural cost, e.g., the cost of the unit amount of steel, should be much less sensitive to total quantity than should either superconductors or refrigeration.

The reduction in unit refrigeration cost principally results from savings in compressor cost, which is the major component of. refrigeration cost. Unit costs for compressors decrease rapidly as compressor rating increases.

Large reductions in unit superconductor cost are expected to result from the much larger production volumes necessary for a fusion power reactor economy. In a previous study, hereafter referred to as the Phase I study, $(1,2)$ superconductor prices were projected using present processing technology. but for superconductor production plant sizes appropriate to a fusion reactor economy. Detailed plant design and cost esti-n mating were used in these projections. It was found that large reductions in unit superconductor costs could be expected. Translated into terms of previously published fusion reactor designs, the projected superconductor cost is only a few dollars/kw(e) and is approximately an order of magnitude cheaper than the estimated structure cost. 
The structures in these fusion reactor magnet designs are of the "cold reinforcement" type, illustrated in Figure 1 for a tokamak reactor. In this method all magnetic forces are contained by a cold $(\sim 4 \mathrm{~K})$ structure, which is insulated from room temperature. Load-bearing supports are necessary to carry the structure weight, but they do not carry magnetic forces. Because of the brittle nature of ordinary stiuctural materials at $4 \mathrm{~K}$, stainless steel must be used for reinforcement of the cold structure. Since stainless steel is expensive, fusion reactor magnets a re generally designed to operate with structural stresses of 50,000 to $100,000 \mathrm{psi}$ to minimize structure cost. Such high stresses and consequent large strains impose severe demands on superconductors, paxticularly $\mathrm{Nb}_{3} \mathrm{Sn}$. In this paper we examine a different method of magnet construction, the "warm reinforcement" type illustrated in Figure 2. Here the magnetic forces are carried through a relatively thin layer directly to room temperature, and the actial containment of the magnetic forces is supplied by a massive structure at room temperature which can be fabricated from ordinary carbon steel, reinforced concrete, rock, etc. The thin layer between 4 and $300 \mathrm{~K}$ is a "thermal barrier," and must have low thermal conductivity, high strength, and high modulus. 
This type of reinforcement is impractical for small magnets but has significant advantages for large magnets of the size needed for fusion reantors. The use of cheap structural material permits large savings in magnet cost even when the extra refrigeration cost for the thermal barrier is included, and also permito much lower structural stresses, since more reinforcement can be economically used. In addition, a room temperature conducior (e.g., aluminum) circuit can be coupled closely inductively to the superconductor, pernitting most of the magnet energy to be dumped at room temperature instead of $4 \mathrm{~K}$ if the superconductor quenches. Finally. in the special case of tokamaks, warm reinforcement permits much more pulger iron in the critical "throat" area (i.e., the inner part of the toroid). At high fields, cold reinforcement takes so much throat area that the pulser iron is insufficient to carry the pulsed field that establishes the plasma ring current, ind a more costly and difficult air core transformer is required.

In the balance of this paper warm and cold reinforcement magnets for a number of different tokamak sizes are compared, for both DT and DD fuel cycles. It is found that at low fields cold and warm reinforcement magnet component costs are comparable, but for high $B_{0}$ (central plasma field) (70 kG and above) large savings can be expected with warm reinforcement. 
In particular, the magnets for the catalyzed DD cycles look. to be economically practical. DESCRIPTION OF THERMAL BARRIER

Figure 3 shows an idealized view of a thermal barrier. The superconductor is wound as a simple pancalke coil, one of the $\sim 50$ toroidal field coils of the tokamak reactor.

(We do not consider here diverter, vertical stability, and ohmic heating coils. While important, they do not appear to be as significant economically or structurally as the toroidal field coils.) Wound on top of the superconductor coil are many interleaved layers of epoxy-fiberglass (which need not be continuous) and stainless stewl strip (which must be continuous). Typically, one-third of the total barrier thickness would be stainless steel and two-thirds epoxy-fiberglass. This layered structure is assumed isotropic, with an average modulus given by the volume averaged moduli of its components. In effect, since the moduli of epoxy-fiberglass are much lower than that of stainless steel, the average modulus of the barrier is essentially that of stainless multiplied by its volume fraction.

The thermal conductivity of stainless is assumed to be effectively infinite, so that the barrier thermal conductivity is determined by the effective thermal conductivity and total 
thickness of epoxy-fiberglass. In Figure 3, refrigeration power and cost for the barrier are reduced by having two intermediate heat sinks (at 20 and $77 \mathrm{k}$ ) between the 4 and $300 \mathrm{~K}$ boundary temperatures. This design is not optimized; one can further reduce consiadrably refrigeration power requirements by having more intermediate heat sinks. However, since refrigeration unit wapital cost decreases rapidly with increasing refrigeration load, it would be better not to use separate refrigeration cycles for each heat sink but rather to use the multi-shield approach where one refrigeranc cools a number of points as it climbs in temperature.

The thermal conductivity and strength of some candidate materials for the epoxy-fiberglass layer are shown in Table 1 , as taken from the available itecature. ${ }^{(3-6)}$ operating in vacuum results in a considerably lower thermal conductivity than in helium gas at 1 atm. Compressive strengths of epoxyfiberglass are on the order of $100,000 \mathrm{psi}$ at cryogenic temperatures and $50,000 \mathrm{pgi}$ at room temperature. Glass fiber-imiaite resin and potassium titanate-epoxy seem to have substantially lower thermal conductivities than epoxy-fiberglass, though the mechanical strength may not be sufficient. Nylon would be of interest for the 4 to $20 \mathrm{~K}$ range. 
The effective thermal conductivity of the laminated epoxy-fiberglass, stainless steel composite will be substantially lower than that of bulk epoxy-fiberglass because of interfacial thermal contact resistance. Mikesell and Scott ${ }^{(7)}$ have shown that for stacks of metal plates the effective thermal conductivity can be as 10 as $2 \%$ of the bulk metal conductivity. The effective value depends on the plate thickness, compressive stress, material modulus and surface cleanliness. For this paper we take the effective averagre the:emal conductivity (including interface contract resistance) for epoxy-fiberglass sheets in vacuum to be $0.4 \mathrm{~mW} \mathrm{~cm}^{-1} \mathrm{~K}^{-1}$ for the 4.5 to $20 \mathrm{~K}$ temperature interval, $0.7 \mathrm{mw} \mathrm{cm}^{-1} \mathrm{~K}^{-1}$ for the 20 to $77 \mathrm{~K}$ interval, and $1.5 \mathrm{~mW} \mathrm{~cm}^{-1} \mathrm{~K}^{-1}$ for the 77 to $300 \mathrm{~K}$ interval. This corresponds to an effective thermal resistance, including interface effects of approximately double that of bulk epoxy-fiberglass.

The maximum compressive stress on the epoxy-fiberglass that would be encountered in any of the magnets considered in this paper is on the order of $10,000 \mathrm{psi}$, approximately an order of magnitude smaller than the compressive strength. At these relatively light loadings no fracture or creep problems are to be expected.

The refrigeration factors and capital costs used in this paper (summarized in Table 2) were taken from a study on 
underground cryogenic power transmission lines. ( $(8)$ They are essentially the same as these given by Kurti (9) though Kurti's capital costs and refrigeration factors both tend to be somewhat lower.

Although the refrigeration factor, $(W(e) / W(t h))$, tends to drop slightly with increasing refrigeration load, the principal reduction is in capital cost $(\$ / W(t h))$, since the major part of the capital cost is for compressors and their unit cost decreases rapidly with increasing size. The refrigeration loads appropriate to a $1000 \mathrm{MW}(\mathrm{e})$ fusion reactor with warm reinforcement and a first wall flux of $1 \mathrm{wW}(\mathrm{th}) / \mathrm{m}^{2}$ are indicated in Table 2. These loads only include heat leaks through the thermal barrier and to not include heat leaks though superinsulation, to transfer 1ines, etc. which will be required whether warm reinforcement is used or not. Including these refrigeration loads will further reduce unit refrigeration capital cost.

These refrigerator costs and efficiencies assume that three separate plants are built for the 4,20 , and $77 \mathrm{~K}$ sinks. Actually, it is much more likely that an integrated plant would be built with a common refigerant (helium) and common compressors. The unit capital refrigeration costs should be considerably lower in this case. 
Included in Table 2 are the capitalined power costs for running the refrigerators. They are comparable to the initial capital cost for the refrigerator.

The total cost from Table 2 is then used to find the optimum thermal barrier thickness, as shown in Table 3. As barrier thickness increases, refrjgeration cost decreases but material costs increase. The optimum barrier thickness is determined by the minimum total cost, and is on the order of 0.5 meters. Thinner barriers $(0.3 \mathrm{~m})$ and thicker barriers $(0.8 \mathrm{~m})$ both show larger total cost. SELECIION OF TOKAMAK FUSION REACTORS TO BE COMPARED Five reactors using warm reinforcement magnets were selected to be paired with five reactors using cold reinforcement magrets. Each pair had the same plasma dimensions and fuel cycle. The first two pairs had DT fuel cycles with plasma minor diameters of 1.0 and 1.5 (relative); the remaining 3 pairs had catalyzed DD fuel cycles with plasma minor diameters of $1.0,1.5$, and 2.0 (relative). All reactors had the same plasma aspect ratio 3.75 , and the same first wall flux, $1 \mathrm{MW}(\mathrm{th}) / \mathrm{m}^{2}$. A relative plasma minor diameter of 1.0 corresponds to an actual plasma minor diameter of 5.6 meters, while 1.5 corresponds to 8.4 meters, and 2.0 to 11.2 meters. The DT case with relative plasma minor diameter of 1.0 was chosen to correspond exactly with the ORNL tokamak design (10) 
except that the ORNL design had a first wall flux of $3.45 \mathrm{NW}(\mathrm{th}) / \mathrm{m}^{2}$. The lower wall flux of $1.0 \mathrm{NW}(\mathrm{th}) / \mathrm{m}^{2}$ for this paper was chosen to be conservative from a radiation damage point of view. Magnet costs in $\$ / \mathrm{kW}(\mathrm{e})$ for different first wall loadings can be readily calculated if desired. Plasma stability values $\left(q_{0} \beta_{\theta}\right)$ as a function of central plasma field $\left(B_{0}\right)$, and plasma minor diameter $\left(D_{p}\right)$ are the same as in the ORNI design, except for a scale factor change due to the lower first wall flux. The ratio of plasma diameter to first wall diameter was taken as 0.8 , as in the ORNL design. DT reactors had a blanket plus shield thickness of $2.0 \mathrm{~m}$, while catalyzed DD reactors had $1.0 \mathrm{~m}$. The relative plasma reaction rates for catalyzed DD and DT fuel cycles were taken from Mi11s. (11)

\section{STRESS ANALYSIS OF MAGNETS}

Dimensions for the warm reinforcement magnets are given in Table 4. These correspond to the plasma and blanket dimensions given earlier. For all cases, the superconductor thickness is taken as $0.15 \mathrm{~m}$, the thermal barrier thickness as 0.5 meters, and the aluminum thickness as 0.3 meters. The reinforcement thickness varies for each case and is fixed by the condition that the reinforcement (i.e., ordinary steel) completely fills the center of the toroid. (Because the stress analysis is 2-dimensional, the equivalent 2-D reinforcement 
thickness is used for the actual wedge shape of the reinforcement at the inner part of the coil.)

Dimensions for the cold reinforcement magnets are also given in Table 4. Here several reinforcement thicknesses are analyzed for each of the five basic cases, so that all can be compared on the basis of equal maximum stress. By interpolation the reinforcement thickness corresponding to the maximum allowed stress in the stainless (for this study, 55,000 psi) is determined. This minimizes the amount of expensive stainless steel. The superconductor and stainless reinforcing strip are wound together in a circular coil (Figure 4). Extra support against coil centering forces is provided by a solid stainless support on the inside of the coll, extending along $40 \%$ of its arc length, and equal in thickness for the circular wound portion. This solid support could either be a forging or made from stacked welded plates. Central compression rings (shown in Figure 1) carry the actual centering loads. The shape of the solid support was optimized by a number of analyses of different shapes.

This cold reinforcement design iffers from ORNL ${ }^{(10)}$ in that here the stainless steel reinforcing strip provides the major portion of coil reinforcement instead of an outside circular solid reinforcing ring, which appears to be more expensive. 
It also differs from the Princeton " $D$ " shaped constant tension coil (12) which in principle should require less reinforcing material, though a larger amount of superconductor.

Because of the heterogeneous structure and non-uniform loadings, it was necessary to use numerical methods for stress analysis.

Magnet stress determinations were made through the use of a computer code developed at BNL by $M$. Reich. The code, written for the Brookhaven CDC 6600 system, is a finite element routine designed to evaluate the stresses and deflections in any twodimensional heterogeneous structure. It accepts as input any combination of force, displacement, and thermal boundary conditions. It provides as output a complete listing of the resultant structural deformations and stresses at all points in the structure. Previously it has been successfully employed to evaluate structures as heterogeneous as prestressed concrete reactor vessels, mine tunnel cross sections with reinforcing bolts, and concrete desalination vessels.

To use the code it is necessary to divide the structure to be analyzed into triangular finite elements. Each element is numbered and in addition each triangle vertex point (node point) is numbered. The resultant figure is referred to as the finite element grid. As it is evident that each triangular element is 
delineated by its three associated nodal points only the nodal point numbering sequence is actually shown on a gria. Next the physical properties of each element (modulus of elasticity, density, etc.), the $X$ and $Y$ location of each node point and the desired nodal force-displacement conditions are specified and the problem is run. Since the physical properties of each element are separately specified the evaluation of heterogeneous structures are readily handled. The normal stresses in the $x$ and $Y$ directions, the $X Y$ shear stress and the maximum and minimum principal stresses for each element are computed. In addition, the above stresses plus the $X$ and $Y$ deflections of all nodal points are computed. With the present version of the code a system consisting of 2400 elements and 1400 nodes may be analyzed.

Typical finite element grid representations of the cold and warm reinforcement coils are shown in Figures 4 and 5 . Obviously, the node point $X$ and $Y$ locations were varied from case to case and the size of elements varied so as to obtain more detailed results in regions of high stress gradient. The force distribution was taken as a radially outward (i.e., along the minor radius vector) acting load varying inversely with the toroidal major radius. It was taken as an internal pressure load in cases 47 through 55 (Table 4) and as a linearly varying body 
load in cases 1 through 47 (load varying from a maximum on the inner minor radius to zero on the outer minor radius of the coil). Typical maximum principal stress contour plots are shown in Figure 6 and 7. The discontinuities apparent in Figure 6 are due to the abrupt changes in material properties inherent in the layered warm reinforcement coil structure.

The calculated stresses in the structure scale directiy with $\left(B_{0}\right)^{2}$, as expected. The location of the maximum stress point does not vary with $\left(B_{0}\right)^{2}$, but can change if coil aimensions change.

Table 5 summarizes and compares the stress analyses for the basic cases. The magnets with warm reinforcement have constant reinforcement thickness and stress thus increases as $B_{0}$ increases. The magnets with cold reinforcement have constant maximum stress $(55,000 \mathrm{psi})$ and the reinforcement thickness thus increases with $B_{0^{*}}$ Even at the very highest fields, however, the stress in magnets with warm reinforcement is much less than that with cold reinforcement. For DT fuel cycles, the range of $B_{0}$ considered is 30 to $70 \mathrm{kG}$. The lower limit is set by plasma stability, the upper, by the estimate that stability does not require higher fields, even if pessimistic scaling laws are used. For catalyzed DD fuel cycles a range of 50 to $90 \mathrm{kG}$ is considered; the lower limit is set by plasma stability, the upper by $\mathrm{Nb}_{3} \mathrm{Sn}$ conductor limits for the smaller magnets. 


\section{RESULTS OF ANALYSIS}

Table 6 summarizes the refrigeration parameters for the ten selected cases. The barrier refrigeration loads are well within the current state-of-the-art. The input power to the refrigerators is less than $1 \%$ of the reactor gross output electric power. Further optimization and combination of the three refrigerator cycles will substantially lower the refrigerator power input and cost.

Table 7 summarizes the magnet component costs for the ten selected cases as a function of magnetic field. Only naterial costs are included; these are better defined than winding and assembly costs. However, preliminary BWL atudies indicate that winding and assembly costs should be small compared with material costs. The thermal barrier refrigeration costs are only about $10 \%$ of the total warm reinforcement magnet component cost.

For the cold reinforcement magnets the amount of pulser iron is set by the condition that the iron swings from +22 to -22 kG during the pulse. In two cases, there is insufficient iron in the throat to carry this pulser field. For the warm reinforcement magnets, there is much more pulser iron since it is used for reinforcement and the field change is much smaller, typically +5 to $-5 \mathrm{kG}$. This permits much longer pulse operation 
with warm reinforcement magnets, since the excess iron can supply the $\Delta H_{v}$ needed to overcone $I / R$ decay of the plasma ring current.

Material costg reflect large volume current market prices: i.e., $\$ 0.08 / 1 \mathrm{~b}$ for pulger iron, $\$ 0.50 / 1 \mathrm{~b}$ for fiberglass, roving, $\$ 0.50 / 1 b$ for exoxy, etc.

The results are presented graphically in Figures 8 and 9 as cost in $\$ / \mathrm{kW}(\mathrm{e})$ as a function of $\mathrm{B}_{0^{\circ}}$ At low fields for both DT and catalyzed-DD fuel cycles, warm and cold reinforcement magnets have comparable costs. With further refrigeration optimization, the warm reinforcement costs should drop somewhit, bringiny cold roinforcement and warm reinforcement costis to essentially the same value. However, at higher fields warm reinforcement magnets are considerably cheaper. Unit magnet costs increase as plasma diameter increases, as would be expected, but this is a relatively small effect.

The total magnet component cost for cold reinforement approximately scales as $\mathrm{B}_{0}^{2}$, since additional structure is needed as field increases. However, the total cost for warm reinforcement increases only slightly with $B_{0}$ since the amount of structure is taken as independently of $B_{0}$ (i.e.. the stress increases as $\mathrm{B}_{0}^{2}$ ), and the only component of cost that increases with $B_{0}$ is the superconductor material cost. 
The plasma stability parameters are shown in Figures 8 . and 9 as a function of $B_{0}$ for DT and catalyzed-DD fuel cyclos. For DT fuel cycles economical warm reinforcement magnets can be built even with unfavorable plasma stability parameters, i.e., $q=3, \beta_{\theta}=2$. The cost would only increase slightly even if $q=3, B_{\theta}=1$. Even lower first wall loadings $\{i . e .$, $0.5 \mathrm{MW}(\mathrm{th}) / \mathrm{m}^{2}$ ) could be used and the magnet would be still economically practical. It, thus, appears that even if one assumes very unfavorable plasma containment and very poor materials behavior, DT magnets will be of reasonable cost. For catalyzed-DD fuel cycles and reasonable stability parameters $\left(q=2, \beta_{\theta}=3\right.$ ) warm reinforcement magnets should be economically practical $(\sim \$ 40 / \mathrm{kW}(\mathrm{e}))$. In fact, $B_{0}$ could increase to $\sim 150 \mathrm{kG}$ without exceeding a maximum stress of $50,000 \mathrm{psi}$ in the structure. However, $\mathrm{Nb}_{3} \mathrm{Sn}$ could not be used to give $\mathrm{B}_{0}$ much above $100 \mathrm{kG}$, even if one operated at temperatures below $4 \mathrm{~K}$, because the field at the inner part of the coil would exceed the capability of $\mathrm{Nb}_{3} \mathrm{Sn}$. However, it appears that cryogenic aluminum could be used to produce $B_{\circ}$ above $110 \mathrm{kG}$ if suitably reinforced against excessive compressive stress, at a relatively small additional magnet cost. Thus even with poor plasma containment $\left(q=3, \beta_{\theta}=2\right)$ it should be economically feasible to build catalyzed-DD fusion reactors. 
MAGNET CONSTRUCTION

The construction of the warm reinforcement magnets should be relatively straightforward. The principal problem is to compensate for the differential shrinkage betweer the siperconductor and the warm reintorcement. This would be done in two different ways; either by winding the superconductor and then prestressing it in compresaion by winding the warm reinforcement layer under tension, or by cooling flown the superconductor layer to liquid $\mathrm{N}_{2}$ temperature fiar the greatest part of the contraction occurs to this temperaturel and then winding on the warm reinforcement layer. In the first method, the superconductor inevitably sees a relatively high compressive stress until cool-down in the second, it does not see a high compressive stress until warm-up. However, the compressive stresses can be readily carried by the superconductors contemplated, i.e., $\mathrm{NB}-\mathrm{Ti}$ and $\mathrm{Mb}_{3} \mathrm{Sn}$.

The toroidal field coils for the reactors in this paper were assumed to be simple pancakes of constant width, with a $20 \%$ gap between coils at the inner part where the major toroidal radius is the least. In actual practice, part of the steel for the warm reinforcement coils would have to be properly tapered on this inner part, so that the converging coils would fit together. This could easily be done by winding this part of the warm reinforcement steel as wire wrap in a proper coil form. 
Further reductions in magnet cost could be anticipated if cheaper strong stronger structural materials than ordinary steel could be used. One such possibility would be rock, i.e., granite. The magnet coil system could be simply imbedded in a suitably shaped cavity underground, with proper shimming and/or grouting, and the rock could carry the load. Competent granite can carry $30,000 \mathrm{psi}$ in compression and should be suitable for this purpose. If tension cracks do occur, the constraining nature of the surrounding rock should prevent any significant movement. This topic deserves further investigation. In conversations with $W$. Hassenzahl, (13) it was learned that this approach has been considered for large energy storage magnets. SUMMARY AND CONCLUSIONS

The principal conclusions of this study are:

1. Warm reinforcement should greatly reduce the cost of high field magnets for fusion reactors. The extra refrigeration cost is small compared with the savings in structure cost. The refrigeration and thermal barrier designs examined in this paper have not been optimized, and it is expected that optimization will show substantially smaller refrigeration costs for warm reinforced magnets. 
2. Magnets for catalyzed-DD reactors appear to be economically practical, on the order of $\$ 40 / \mathrm{kW}(e)$. This would eliminate the tritium breeding blanket necessary for DT reactors, which promises difficult technological problems.

3. For tokamak reactors, it appears possible from a structural stress standpoint to use $B_{0}$ "s of up to $150 \mathrm{kG}$. This would permit economically practical magnets even if plasma containment should be very poor. Such fields could not be achieved with $\mathrm{Nb}_{3} \mathrm{Sn}$ superconductors, however, even if they were operated below $4 \mathrm{~K}$, and cryogenic aluminum or ultra-high-fielo superconductor inserts would be required.

4. If plasma stability and containment proves good, however, the lower fields will reguit in quite low structural stresses in magnets with warm reinforcement, in fact. several times less than those in magnets with cold reinforcement.

5. An intriguing possibility exists with warm reinforcement, that of using a massive rock structure to carry the magnetic forces. Such an underground structure, besides providing even cheaper material to carry the magnet forces than the ordinary steel assumed in this paper, would be useful as protective containment for the fusion reactor. 


\section{ACKNOWLEDGMENT}

The authors wish to express their grateful appreciation to Dr. William Gough, U.S. Atomia Energy Commission for his support of these studies, and to Mrs. Eleanor c. Dahl and Mrs. Gwen Bergin for typing the manuscript. 


\section{REFERENCES}

1. Powell, J. R. Costs of Magents for Iarge Fusion Power Reactors: Phase I, Cost of Superconductors for dc Magnets. Brookhaven National Laboratory Informal Report, BNL 16580, Feb. 25, 1972.

2. Powell. J. R. Design and Economics of Iarge de Fusion Magnets, Proc. 1972 Applied Superconductivity Conference. IEEE Pub. No. 72CHO682-5-TABSC, p. 374, MaY 1-3, 1972, Annapolis, Maryland.

3. Toth, L. W. Properties of Glass-Reinforced Epoxy through the $20 \mathrm{k}$ Range, Nodern Plastics, p. 123, Aug. 1965.

4. Campbel1, M. D. et al. Thermophysical properties of Plastic Materials and Composites to Liquid Fydrogen Temperature (-423 F), MI-IDR-64-33, Part III, Aug. 1965.

5. Hertz, J. Investigation of Potential Low Temperature Insulators, Advances in Cryogenic Engineering, 11,

P. 287, Plenum Press, New York, 1966.

6. Ashworth, T., Loomer, J. E., and Kreitman, M. M. Thermal Conductivity of Nylons and Apiezon Greases, Paper F-3. Cryogenic Engineering Conference, Boulder, Colorado, 1972.

7. Mikesel1, R. $\dot{\text {. }}$. and scott, R. B. Heat Conduction through Insulating Supports in Very Low Temperature Equipment, J. Res. of Nat'1 Buz. Std. 57, 371 (1956). 
8. Resistive Cryogenic Cable, Phase A and Phase B report. General Electric Company, EEI Project RP-78-6 (1969).

9. Kurti, N. Crvogenic Fundamentals, G. G. Haselden, Editor, Academic Press, 1971.

10. Lubell, M. S. et al. Engineering Design Studies on the Superconducting Magnet Syatem of a Tokamak Fusion Power Reactor, Paper CN-28/K-10, 4th IMEA Conf. on Plasma Physics and Controlled Thermonuclear Fusion Research, Madison, Misconsin, June 1971.

11. Mills, R. G. Catalyzed Deuterium Fusion Reactor, TH-259, Princeton Plasma Physics Laboratory, Apr. 1971.

12. File, J., Mills, R. G., and Sheffield, G. V., Large Superconducting Magnet Designs for Fusion Reactors, MATT-848, Princeton Plasma Physics Iaboratory, June 1971.

13. Hassenzahl, W., Los Alamos National Laboratory, private communication. 1972. 
TRBLE 1

PROPERTIES OF CNIDIDATE MATERTAIS FOR THERMI BARETER

\begin{tabular}{c} 
Sample \\
no. \\
\hline $1-7$ \\
1 \\
2 \\
3 \\
4 \\
5 \\
$5 A$ \\
6 \\
7 \\
8 \\
9 \\
10 \\
$10 \mathrm{~A}$ \\
11 \\
$11 \mathrm{~A}$ \\
12
\end{tabular}

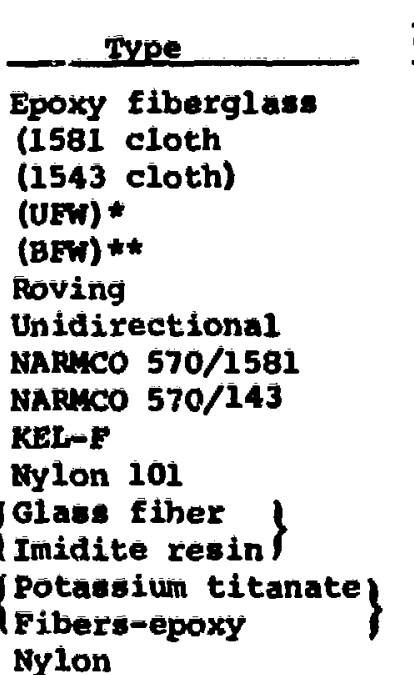

Thermal conductivity \& to Iamina

\begin{tabular}{|c|c|c|c|}
\hline$T=4^{\circ} \mathrm{K}$ & 20 & 77 & 300 \\
\hline$-\infty$ & - & 0.79 & 9.8 \\
\hline$=$ & $\Rightarrow$ & 0.90 & 11.0 \\
\hline$-\infty$ & - & 1.35 & 10.9 \\
\hline$=\infty$ & $=-$ & 0.92 & 10.5 \\
\hline - & 1.30 & 2.45 & \\
\hline$-\infty$ & 0.58 & 1.73 & \\
\hline$-\infty$ & 1.10 & 2.10 & 1.3 \\
\hline$-\infty$ & 1.20 & 2.20 & \\
\hline$=$ & $\begin{array}{l}0.56 \\
1.00\end{array}$ & $\begin{array}{l}1.10 \\
2.50\end{array}$ & $\begin{array}{l}1.4 \\
3.4\end{array}$ \\
\hline- & 1.60 & 3.20 & 5.0 \\
\hline$-\infty$ & 0.29 & 1.20 & 3.6 \\
\hline$-\infty$ & 1.20 & 2.20 & 4.3 \\
\hline$-\bar{x}$ & 0.43 & 1.20 & 1.6 \\
\hline 0.13 & 0.95 & 2.70 & 3.7 \\
\hline
\end{tabular}

Teat atin

Compresive etrength 2

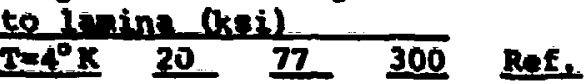

to in (ki)

Eiberglas

cloth

Roving

Unidirections

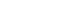

vac
vac
vac

$\begin{array}{lllll}- & 101 & 95 & 59 & 3\end{array}$

$\begin{array}{lllll}- & 52 & 52 & 25 & 36\end{array}$

He, 1 atm

vac $-\infty \quad 73 \neq 4$

He. 1 atm $\quad-\quad 134 \quad 139 \quad 76 \quad 5 t$

He, 1 atm $=010172$

He, 1 atm

He. 1 atm

$-$

He. 1 atin vac

He, 1 atm

vàc

$-\infty \quad-$

$-$

$\bar{z}$

$--$

$20 \quad 17$

$-35$

$-\infty$

$=$

Nyion

0.13

$0.95 \quad 2.70$

*Unidirectional filamentary winding.

** Bidirectional filamentary winding.

tTensile strength || to lamina, coipressive strength not given.

Fower than reported in the literature, possibly poor quality. 
TABIS 2

REFRIGERATIOA PARNIETERS FOR FUSIOA REACTORS WITH WAFU REIMYORCEUEITP

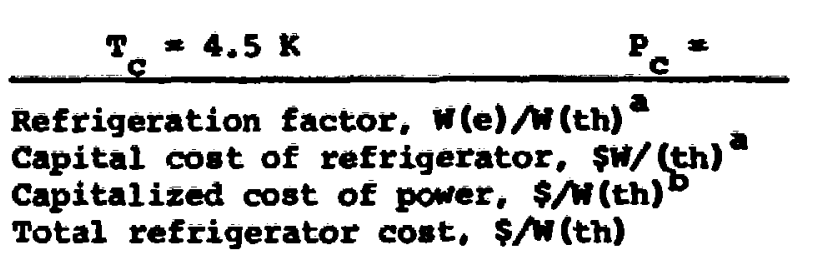

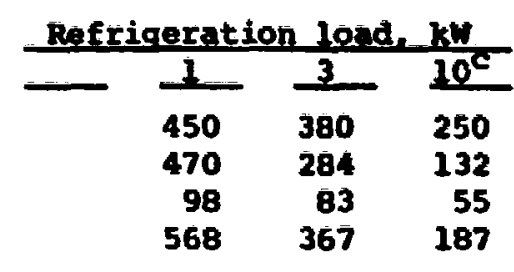

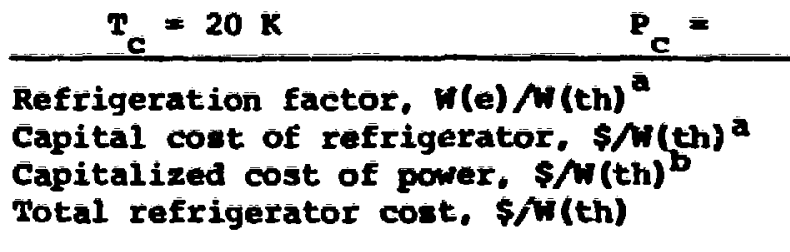

\begin{tabular}{|c|c|c|c|}
\hline $100^{\circ}$ & 200 & 300 & 900 \\
\hline $\begin{array}{l}45.6 \\
20.0 \\
10.0 \\
30.0\end{array}$ & $\begin{array}{l}45.5 \\
12.6 \\
10.0 \\
22.6\end{array}$ & $\begin{array}{r}43.5 \\
9.9 \\
9.5 \\
19.4\end{array}$ & $\begin{array}{r}42.3 \\
8.5 \\
9.3 \\
17.8\end{array}$ \\
\hline & $500^{\circ}$ & 1000 & 2000 \\
\hline & $\begin{array}{l}9.6 \\
2.3 \\
2.1 \\
4.4\end{array}$ & $\begin{array}{l}7.70 \\
1.85 \\
1.70 \\
3.55\end{array}$ & $\begin{array}{l}7.55 \\
1.55 \\
1.65 \\
3.20\end{array}$ \\
\hline
\end{tabular}

$a_{\text {Refrigeration factor and capital cost of refrigerators taken }}$ from Ref. 8 .

${ }^{b}$ Cost of refrigerator power is 4 mils/kwh; capital charges of $16 \% / y r$.

CRefrigeration load from thermal barrier appropriate to 1000 inf(e) fusion reactor with warm reinforcement and a first wall flux of $1 \mathrm{MW}(\mathrm{th}) / \mathrm{m}^{2}$. 
TABLE 3

COST OF THERMAL BARRIER FOR DIFFERENT BARRIER THICKNESS

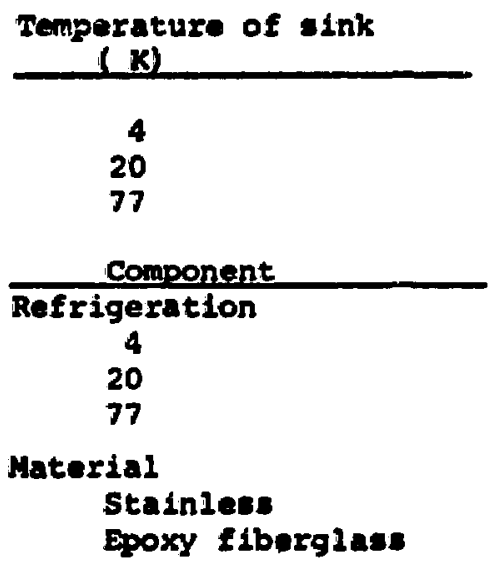

Total

\begin{tabular}{|c|c|c|}
\hline Refrigeratis & $120 \mathrm{ad}$ & $\mathrm{w} / \mathrm{m}$ \\
\hline$\Delta x(m)=0,3$ & 0.5 & $\underline{0.8}$ \\
\hline $\begin{array}{r}9.3 \\
50.5 \\
451.0\end{array}$ & $\begin{array}{r}5.6 \\
30.3 \\
271.0\end{array}$ & $\begin{array}{r}3.5 \\
18.9 \\
169.0\end{array}$ \\
\hline
\end{tabular}

Cont of thermal barrier. $\$ / \mathrm{m}^{2}$ $\underline{\Delta x(m)}=\underline{0.3} \quad \underline{0.5} \quad \underline{0.8}$

\begin{tabular}{rrr}
1745 & 1047 & 654 \\
1515 & 909 & 568 \\
1985 & 1191 & 744 \\
& & \\
1156 & 1850 & 3083 \\
404 & 647 & 1078 \\
\hline 6805 & 5644 & 6127
\end{tabular}

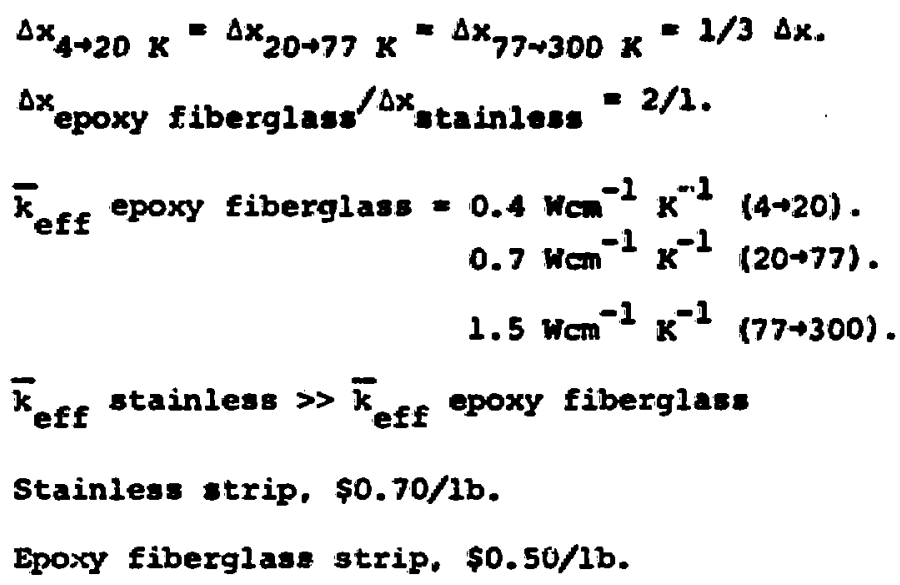


ThBre 4

MeNETS NMIYZED

\begin{tabular}{|c|c|c|c|c|c|c|c|c|c|c|c|c|c|}
\hline \multirow[b]{2}{*}{$\begin{array}{l}\text { Case } \\
\text { no. }\end{array}$} & \multirow[b]{2}{*}{$\begin{array}{l}\text { Reactor } \\
\text { type }\end{array}$} & \multirow[b]{2}{*}{$\begin{array}{c}\mathbf{R F} \\
\text { tyoe }\end{array}$} & \multirow[b]{2}{*}{$\begin{array}{r}R_{i} \\
\end{array}$} & \multirow[b]{2}{*}{$\begin{array}{c}R_{0} \\
(w)\end{array}$} & \multirow[b]{2}{*}{$\begin{array}{l}R_{T} \\
(0)\end{array}$} & \multicolumn{3}{|c|}{ AB thicknes: } & \multirow[b]{2}{*}{$\begin{array}{c}\mathbf{B}_{\overline{\mathbf{o}}} \\
(\mathbf{k} \overline{\mathbf{G}}) \\
\end{array}$} & \multicolumn{4}{|c|}{ 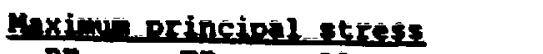 } \\
\hline & & & & & & $\underset{(\omega)}{n}$ & (D) & $\begin{array}{l}A 1 \\
(0)\end{array}$ & & (kei) & $\begin{array}{c}\text { TB } \\
(k s i) \\
\end{array}$ & $\begin{array}{c}n 1 \\
(k \leq i)\end{array}$ & IOc. \\
\hline $\begin{array}{l}41 \\
4 \overline{2} \\
43 \\
44 \\
45\end{array}$ & $\begin{array}{l}\text { DT } \\
\text { DT } \\
\text { DD } \\
\text { DD } \\
\text { DD }\end{array}$ & $\begin{array}{l}\text { warm } \\
\text { warti } \\
\text { warm } \\
\text { warm } \\
\text { warm }\end{array}$ & $\begin{array}{l}5.75 \\
7.49 \\
4.75 \\
6.49 \\
8.25\end{array}$ & $\begin{array}{r}8.55 \\
12.00 \\
8.05 \\
11.52 \\
15.02\end{array}$ & $\begin{array}{l}10.50 \\
15.75 \\
10.50 \\
15.75 \\
21.00\end{array}$ & $\begin{array}{l}2.00 \\
3.71 \\
2.50 \\
4.23 \\
5.97\end{array}$ & $\begin{array}{l}0.50 \\
0.50 \\
0.50 \\
0.50 \\
0.50\end{array}$ & $\begin{array}{l}0.30 \\
0.30 \\
0.30 \\
0.30 \\
0.30\end{array}$ & $\begin{array}{l}60.0 \\
60.0 \\
90.0 \\
90.0 \\
90.0\end{array}$ & $\begin{array}{l}21.99 \\
14.65 \\
27.88 \\
22.70 \\
20.89\end{array}$ & $\begin{array}{r}10.26 \\
6.52 \\
14.24 \\
10.81 \\
8.70\end{array}$ & $\begin{array}{l}7.61 \\
4.90 \\
9.95 \\
7.82 \\
6.93\end{array}$ & $\begin{array}{l}1104 \\
1104 \\
1104 \\
1104 \\
1104\end{array}$ \\
\hline $\begin{array}{r}7 \\
8 \\
10 \\
12 \\
14 \\
17 \\
18 \\
19 \\
20 \\
21\end{array}$ & $\begin{array}{l}\mathbf{D T} \\
\mathbf{D T} \\
\mathbf{D T} \\
\mathbf{D T} \\
\overline{\mathbf{D T}} \\
\mathbf{D T} \\
\mathbf{D T} \\
\overline{\mathbf{D T}} \\
\mathbf{D T} \\
\mathbf{D T}\end{array}$ & $\begin{array}{l}\text { cold } \\
\text { cold } \\
\text { cold } \\
\text { cold } \\
\text { cold } \\
\text { cold } \\
\text { cold } \\
\text { cold } \\
\text { cold } \\
\text { cold }\end{array}$ & $\begin{array}{l}5.60 \\
5.60 \\
5.60 \\
5.60 \\
5.60 \\
7.34 \\
7.34 \\
7.54 \\
7.34 \\
7.34\end{array}$ & $\begin{array}{l}6.74 \\
6.36 \\
5.98 \\
6.11 \\
6.62 \\
7.85 \\
8.10 \\
8.36 \\
8.85 \\
9.34\end{array}$ & $\begin{array}{l}10.50 \\
10.50 \\
10.50 \\
10.50 \\
10.50 \\
15.75 \\
15.75 \\
15.75 \\
15.75 \\
15.75\end{array}$ & $\begin{array}{l}1.14 \\
0.76 \\
0.38 \\
0.51 \\
1.02 \\
0.51 \\
0.76 \\
1.02 \\
0.51 \\
2.00\end{array}$ & $\begin{array}{l}=- \\
=- \\
=- \\
=- \\
=- \\
=- \\
=- \\
=\end{array}$ & $\begin{array}{l}=- \\
=- \\
=- \\
=- \\
=- \\
=- \\
=- \\
=- \\
=-\end{array}$ & $\begin{array}{l}78.5 \\
78.5 \\
37.0 \\
37.0 \\
78.5 \\
37.0 \\
26.2 \\
37.0 \\
78.5 \\
78.5\end{array}$ & $\begin{array}{r}81.21 \\
130.59 \\
84.24 \\
50.53 \\
91.60 \\
68.51 \\
17.60 \\
24.69 \\
68.97 \\
49.98\end{array}$ & $\begin{array}{l}=- \\
=- \\
=- \\
=- \\
=- \\
=- \\
=- \\
=-\end{array}$ & $\begin{array}{l}= \\
=- \\
=- \\
=- \\
=- \\
=- \\
=- \\
=-\end{array}$ & $\begin{array}{r}1 \\
1 \\
645 \\
658 \\
1 \\
645 \\
1 \\
1 \\
1 \\
840\end{array}$ \\
\hline $\begin{array}{l}47 \\
48 \\
49 \\
50 \\
51 \\
52 \\
53 \\
54 \\
55\end{array}$ & $\begin{array}{l}\text { DD } \\
\text { DD } \\
\text { DD } \\
\text { DD } \\
\text { DD } \\
\text { DD } \\
\text { DD } \\
\text { DD } \\
\text { DD }\end{array}$ & $\begin{array}{l}\text { cold } \\
\text { cold } \\
\text { cold } \\
\text { cold } \\
\text { cold } \\
\text { cold } \\
\text { cold } \\
\text { cold } \\
\text { cold }\end{array}$ & $\begin{array}{l}4.60 \\
4.60 \\
4.60 \\
6.34 \\
6.34 \\
6.34 \\
8.10 \\
8.10 \\
8.10\end{array}$ & $\begin{array}{r}5.36 \\
5.87 \\
6.38 \\
7.61 \\
8.12 \\
8.63 \\
9.88 \\
10.39 \\
10.89\end{array}$ & $\begin{array}{l}10.50 \\
10.50 \\
10.50 \\
15.75 \\
15.75 \\
15.75 \\
21.00 \\
21.00 \\
21.00\end{array}$ & $\begin{array}{l}0.76 \\
1.27 \\
1.78 \\
1.27 \\
1.78 \\
2.29 \\
1.78 \\
2.29 \\
2.79\end{array}$ & $\begin{array}{l}=- \\
=- \\
=- \\
=- \\
=- \\
=- \\
=-\end{array}$ & $\begin{array}{l}=- \\
=- \\
=- \\
=- \\
=- \\
=- \\
=-\end{array}$ & $\begin{array}{l}90.0 \\
90.0 \\
90.0 \\
90.0 \\
90.0 \\
90.0 \\
90.0 \\
90.0 \\
90.0\end{array}$ & $\begin{array}{r}110.42 \\
68.79 \\
52.17 \\
84.37 \\
61.90 \\
50.18 \\
74.25 \\
58.78 \\
49.66\end{array}$ & $\begin{array}{l}=- \\
=- \\
=- \\
=- \\
-- \\
=- \\
--\end{array}$ & $\begin{array}{l}== \\
=- \\
-- \\
-- \\
=- \\
-- \\
=- \\
=-\end{array}$ & $\begin{array}{r}1 \\
801 \\
814 \\
1 \\
801 \\
814 \\
1 \\
801 \\
814\end{array}$ \\
\hline $\begin{array}{l}R_{i} \\
R_{0} \\
R_{T}\end{array}$ & $\begin{array}{l}\text { inor in } \\
\text { inor out } \\
\text { adius or }\end{array}$ & radi & & & $=r^{\circ i}$ & $1 E$ & & & & & & & \\
\hline
\end{tabular}

"Loc is the node number on the appropriate finite element grid. 
TMEL 5

COMPARISON OR SMECTED MGET DESIGNS

\begin{tabular}{|c|c|c|c|c|c|c|c|c|c|}
\hline $\begin{array}{l}\text { Cave } \\
\text { no. }\end{array}$ & $\begin{array}{l}\text { Reactor } \\
\text { types }\end{array}$ & $\begin{array}{c}R F \\
\pm y 20\end{array}$ & $R_{i}$ & $\begin{array}{r}\mathbf{R}_{\mathbf{T}} \\
\mathbf{( E )} \\
\end{array}$ & & $\begin{array}{r}R \bar{r} \text { t } \\
(\mathrm{m})\end{array}$ & icknes: & & Coments \\
\hline $\begin{array}{l}1 \\
2 \\
3 \\
4 \\
5\end{array}$ & $\begin{array}{l}\text { DT } \\
\text { DT } \\
\text { DD } \\
\text { DD } \\
\text { DD }\end{array}$ & $\begin{array}{l}\text { warm } \\
\text { warm } \\
\text { warm } \\
\text { warm } \\
\text { warm }\end{array}$ & $\begin{array}{l}5.75 \\
7.49 \\
4.75 \\
6.49 \\
8.25\end{array}$ & $\begin{array}{l}10.50 \\
15.75 \\
10.50 \\
15.75 \\
21.00\end{array}$ & & $\begin{array}{l}2.0 \\
3.7 \\
2.5 \\
4.2 \\
5.9\end{array}$ & & & $\begin{array}{l}\text { strest }=f\left(B_{0}\right) \\
\text { refer to Table }\end{array}$ \\
\hline $\begin{array}{r}6 \\
7 \\
8 \\
9 \\
10\end{array}$ & $\begin{array}{l}\text { DT } \\
\text { DT } \\
\text { DD } \\
\text { DD } \\
\text { DD }\end{array}$ & $\begin{array}{l}\text { cold } \\
\text { cold } \\
\text { cold } \\
\text { cold } \\
\text { cold }\end{array}$ & $\begin{array}{l}5.60 \\
7.34 \\
4.60 \\
6.34 \\
8.10\end{array}$ & $\begin{array}{l}10.50 \\
15.75 \\
10.50 \\
15.75 \\
21.00\end{array}$ & $\begin{array}{c}0.38 \\
0.47 \\
-- \\
=- \\
=-\end{array}$ & $\begin{array}{l}0.74 \\
0.86 \\
0.43 \\
0.57 \\
0.81\end{array}$ & $\begin{array}{l}1.35 \\
1.52 \\
0.94 \\
1.17 \\
1.49\end{array}$ & $\begin{array}{r}-- \\
-. \\
1.68 \\
2.02 \\
2.41\end{array}$ & stress $=55 \mathrm{ksi}$ \\
\hline
\end{tabular}


TABLE 6

OUTPUT POWER AND REFRIGERATOR PARAMETEERS FOR SELECTED FUSION REACTORS

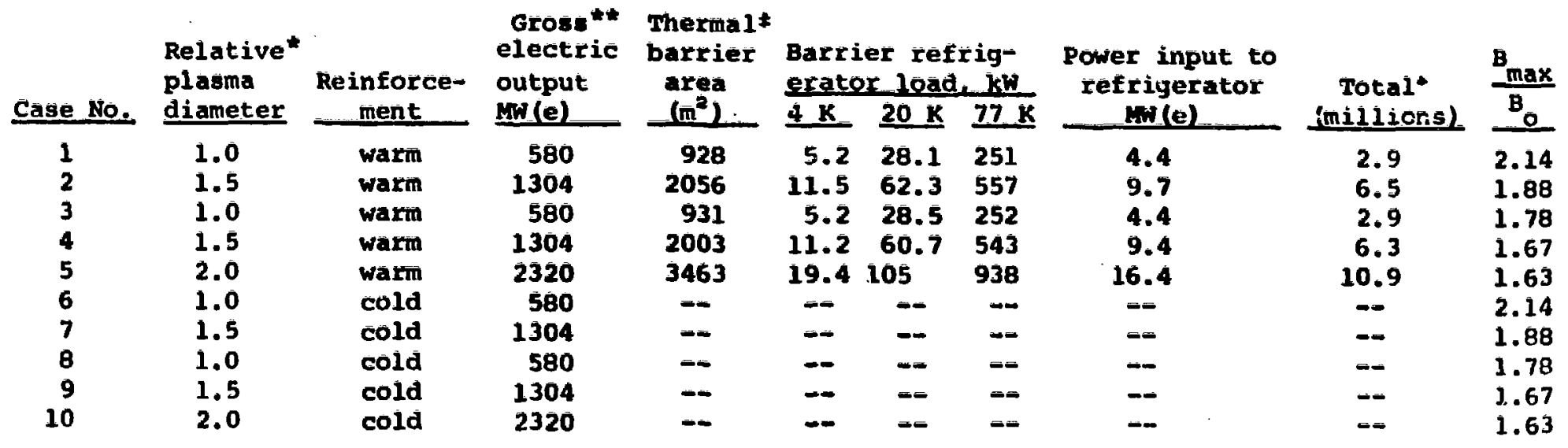

+Refrigeration cost includes capital ized power cost, $4 \mathrm{rils} / \mathrm{kWh}$ at $16 \% / \mathrm{yr}^{\mathrm{r}}$

Thermal barrier thickness $=0.5 \mathrm{~m}$.

* Relative diameter of 1.0 corresponds to real diameter $=5.6 \mathrm{~m}$; plasma aspect ratio $=3.75$.

**irst wall loading $=1.0 \mathrm{~mW}(\mathrm{th}) / \mathrm{m}^{2}$; themal efficiency $=40 \%$. 
TARE: 7

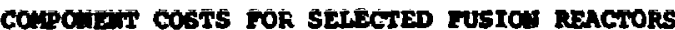

\begin{tabular}{|c|c|c|c|c|c|c|c|c|c|c|}
\hline \multirow[b]{2}{*}{ Calle $\mathrm{NO}_{2}$} & \multirow[b]{2}{*}{$\begin{array}{l}\text { Bo } \\
\text { kE }\end{array}$} & \multicolumn{9}{|c|}{ Cononent cont" rillions } \\
\hline & & $\begin{array}{c}\text { Barrier } \\
\text { refrigerator } \\
\end{array}$ & $\begin{array}{l}\text { super= } \\
\text { conductor }\end{array}$ & $\begin{array}{l}\text { Epoxy } \\
\text { fiber- } \\
\text { glnes }\end{array}$ & Mluminu: & $\begin{array}{l}\text { Stainlese } \\
\text { Steip. }\end{array}$ & $\begin{array}{l}\text { Support } \\
\text { forging }\end{array}$ & $\begin{array}{l}\text { Puleer } \\
\text { iroll }\end{array}$ & Total & $\begin{array}{l}\text { zotal } \\
\text { s/aw(e) }\end{array}$ \\
\hline 1 & $\begin{array}{l}30 \\
50 \\
70\end{array}$ & $\begin{array}{l}2.9 \\
2.9 \\
2.9\end{array}$ & $\begin{array}{l}1.4 \\
3.2 \\
7.3\end{array}$ & $\begin{array}{l}0.6 \\
0.6 \\
0.6\end{array}$ & $\begin{array}{l}0.6 \\
0.6 \\
0.6\end{array}$ & $\begin{array}{l}1.7 \\
1.7 \\
1.7\end{array}$ & $\begin{array}{l}2.0 \\
2.0 \\
2.0\end{array}$ & $\begin{array}{l}3.0 \\
3.0 \\
3.0\end{array}$ & $\begin{array}{l}12.2 \\
14.0 \\
18.1\end{array}$ & $\begin{array}{l}21.0 \\
24.0 \\
31.0\end{array}$ \\
\hline 2 & $\begin{array}{l}30 \\
50 \\
70\end{array}$ & $\begin{array}{l}6.5 \\
6.5 \\
6.5\end{array}$ & $\begin{array}{r}2.6 \\
5.5 \\
11.8\end{array}$ & $\begin{array}{l}1.3 \\
1.3 \\
1.3\end{array}$ & $\begin{array}{l}1.3 \\
1.3 \\
1.3\end{array}$ & $\begin{array}{l}3.8 \\
3.8 \\
3.8\end{array}$ & $\begin{array}{l}6.8 \\
6.8 \\
6.8\end{array}$ & $\begin{array}{l}12.7 \\
12.7 \\
12.7\end{array}$ & $\begin{array}{l}35.0 \\
37.9 \\
44.2\end{array}$ & $\begin{array}{l}27.0 \\
29.0 \\
34.0\end{array}$ \\
\hline 3 & $\begin{array}{l}50 \\
70 \\
90\end{array}$ & $\begin{array}{l}2.9 \\
2.9 \\
2.9\end{array}$ & $\begin{array}{l}2.1 \\
4.3 \\
9.2\end{array}$ & $\begin{array}{l}0.6 \\
0.6 \\
0.6\end{array}$ & $\begin{array}{l}0.6 \\
0.6 \\
0.6\end{array}$ & $\begin{array}{l}1.7 \\
1.7 \\
1.7\end{array}$ & $\begin{array}{l}2.2 \\
2.2 \\
2.2\end{array}$ & $\begin{array}{l}4.0 \\
4.0 \\
4.0\end{array}$ & $\begin{array}{l}14.1 \\
16.3 \\
21.2\end{array}$ & $\begin{array}{l}24.5 \\
28.0 \\
36.5\end{array}$ \\
\hline 4 & $\begin{array}{l}50 \\
70 \\
90\end{array}$ & $\begin{array}{l}6.3 \\
6.3 \\
6.3\end{array}$ & $\begin{array}{r}3.6 \\
8.6 \\
16.0\end{array}$ & $\begin{array}{l}1.3 \\
1.3 \\
1.3\end{array}$ & $\begin{array}{l}1.4 \\
1.4 \\
1.4\end{array}$ & $\begin{array}{l}3.7 \\
3.7 \\
3.7\end{array}$ & $\begin{array}{l}6.6 \\
6.6 \\
6.6\end{array}$ & $\begin{array}{l}15.0 \\
15.0 \\
15.0\end{array}$ & $\begin{array}{l}37.9 \\
42.9 \\
50.3\end{array}$ & $\begin{array}{l}29.0 \\
33.0 \\
38.5\end{array}$ \\
\hline 5 & $\begin{array}{l}50 \\
70 \\
90\end{array}$ & $\begin{array}{l}10.9 \\
10.9 \\
10.9\end{array}$ & $\begin{array}{r}7.3 \\
14.4 \\
26.2\end{array}$ & $\begin{array}{l}2.3 \\
2.3 \\
2.3\end{array}$ & $\begin{array}{l}2.2 \\
2.2 \\
2.2\end{array}$ & $\begin{array}{l}6.5 \\
6.5 \\
6.5\end{array}$ & $\begin{array}{l}15.0 \\
15.0 \\
15.0\end{array}$ & $\begin{array}{l}38.0 \\
38.0 \\
38.0\end{array}$ & $\begin{array}{r}82.2 \\
89.3 \\
201.1\end{array}$ & $\begin{array}{l}35.5 \\
38.5 \\
43.5\end{array}$ \\
\hline 6 & $\begin{array}{l}30 \\
50 \\
70\end{array}$ & $\begin{array}{l}=- \\
== \\
=-\end{array}$ & $\begin{array}{l}1.4 \\
3.3 \\
7.9\end{array}$ & $=$ & $\begin{array}{l}=- \\
z= \\
=-\end{array}$ & $\begin{array}{r}3.6 \\
7.4 \\
14.0\end{array}$ & $\begin{array}{l}1.9 \\
3.9 \\
8.4\end{array}$ & $\begin{array}{l}1.9 \\
2.0 \\
*\end{array}$ & $\begin{array}{r}8.8 \\
16.6 \\
30.3\end{array}$ & $\begin{array}{l}25.2 \\
28.6 \\
52.2\end{array}$ \\
\hline 7 & $\begin{array}{l}30 \\
50 \\
70\end{array}$ & $\begin{array}{l}=- \\
=-\end{array}$ & $\begin{array}{r}2.6 \\
5.7 \\
12.6\end{array}$ & $\begin{array}{l}=0 \\
=\end{array}$ & $=$ & $\begin{array}{l}10.0 \\
20.0 \\
35.0\end{array}$ & $\begin{array}{r}5.4 \\
10.0 \\
21.0\end{array}$ & $\begin{array}{l}5.0 \\
5.3 \\
5.7\end{array}$ & $\begin{array}{l}23.0 \\
41.0 \\
74.3\end{array}$ & $\begin{array}{l}17.6 \\
31.4 \\
60.0\end{array}$ \\
\hline 8 & $\begin{array}{l}50 \\
70 \\
90\end{array}$ & $\begin{array}{l}=- \\
=- \\
==\end{array}$ & $\begin{array}{r}2.2 \\
4.6 \\
10.3\end{array}$ & $\begin{array}{l}= \\
\Rightarrow= \\
x=\end{array}$ & $=$ & $\begin{array}{r}4.5 \\
10.0 \\
19.0\end{array}$ & $\begin{array}{r}2.2 \\
5.5 \\
12.0\end{array}$ & $\begin{array}{l}1.6 \\
1.8 \\
* *\end{array}$ & $\begin{array}{l}10.5 \\
21.9 \\
41.3\end{array}$ & $\begin{array}{l}18.1 \\
37.8 \\
71.2\end{array}$ \\
\hline$\dot{9}^{\circ}$ & $\begin{array}{l}50 \\
70 \\
90\end{array}$ & $\begin{array}{l}=- \\
=- \\
=-\end{array}$ & $\begin{array}{r}3.7 \\
9.1 \\
17.7\end{array}$ & $\begin{array}{l}=- \\
= \\
=\end{array}$ & $\begin{array}{l}=- \\
=\end{array}$ & $\begin{array}{l}13.0 \\
26.0 \\
48.0\end{array}$ & $\begin{array}{r}6.3 \\
15.0 \\
30.0\end{array}$ & $\begin{array}{l}4.5 \\
4.9 \\
5.4\end{array}$ & $\begin{array}{r}27.5 \\
55.0 \\
101.1\end{array}$ & $\begin{array}{l}21.1 \\
42.2 \\
77.5\end{array}$ \\
\hline 10 & $\begin{array}{l}50 \\
70 \\
90\end{array}$ & $=-$ & $\begin{array}{r}7.5 \\
-15.3 \\
28.8\end{array}$ & $\begin{array}{l}= \\
=- \\
=-\end{array}$ & $\begin{array}{l}= \\
=-\end{array}$ & $\begin{array}{r}31.0 \\
59.0 \\
100.0\end{array}$ & $\begin{array}{l}16.0 \\
33.0 \\
61.0\end{array}$ & $\begin{array}{r}9.6 \\
10.2 \\
11.1\end{array}$ & $\begin{array}{r}64.1 \\
117.5 \\
200.9\end{array}$ & $\begin{array}{l}27.6 \\
50.6 \\
86.6\end{array}$ \\
\hline
\end{tabular}

Does not include coil winding costs.

"tinsufficient iron in center of tokamak to supply $\mathrm{Ag}_{\mathrm{v}}=44 \mathrm{kG}$.

$$
\begin{aligned}
& \text { Epoxy fiberglass }=\$ 0.50 / 1 b \\
& \begin{array}{ll}
\text { Aluminum } & =\$ 0.35 / 1 \mathrm{~b} \\
\text { Stainless strip } & =\$ 0.70 / 1 \mathrm{~b}
\end{array} \\
& \text { Support fortisg (iron) } \\
& =\$ 0.20 / 2 b \\
& \begin{aligned}
\text { Support forsing (stainless) } & =\$ 1.00 / 1 \mathrm{~b} \\
\text { Pulser izon } & =\$ 0.08 / 1 \mathrm{~b}
\end{aligned}
\end{aligned}
$$




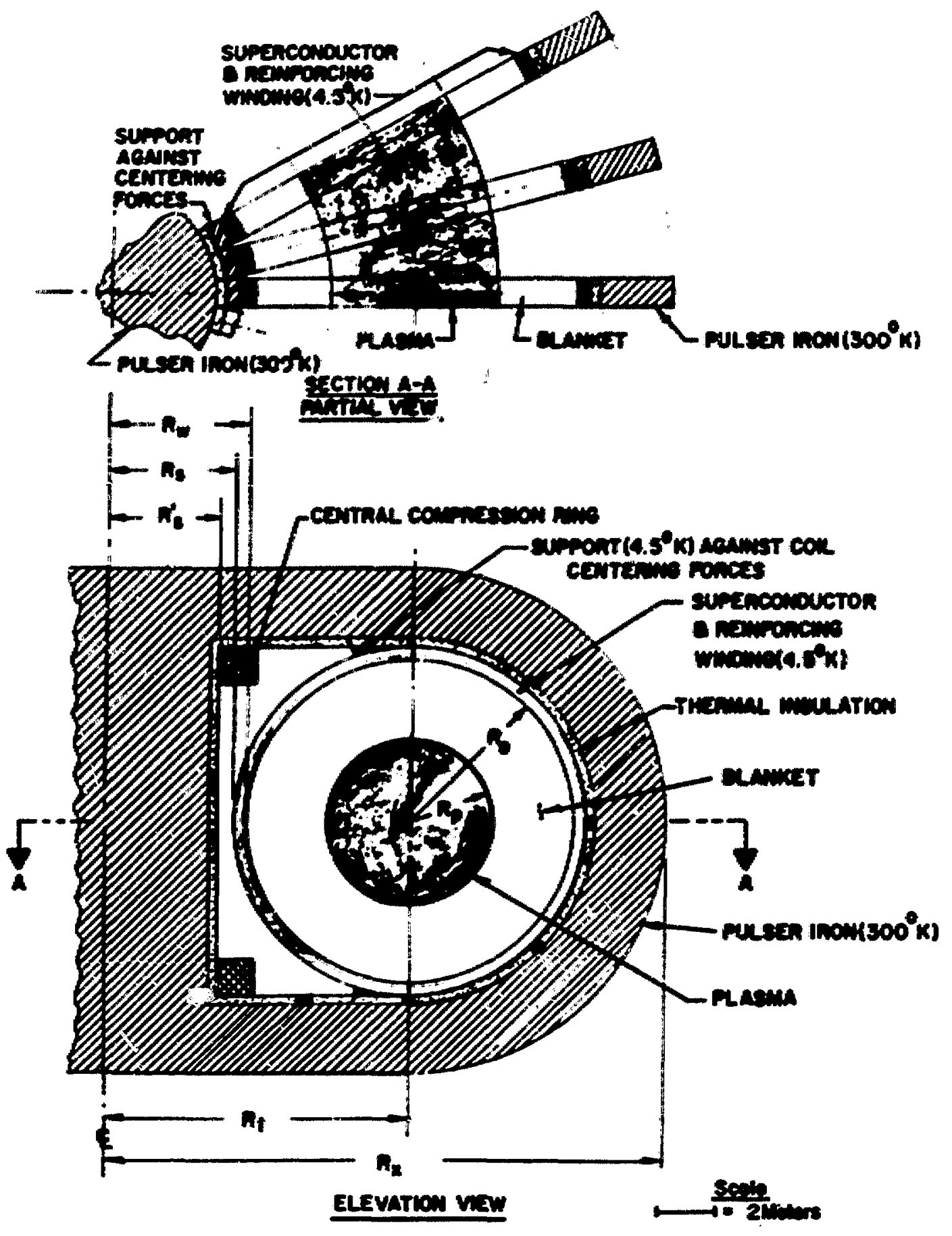

Figure 1 Illuatration of cold reinforcement magnet coil for tokamak fusion reactor. 


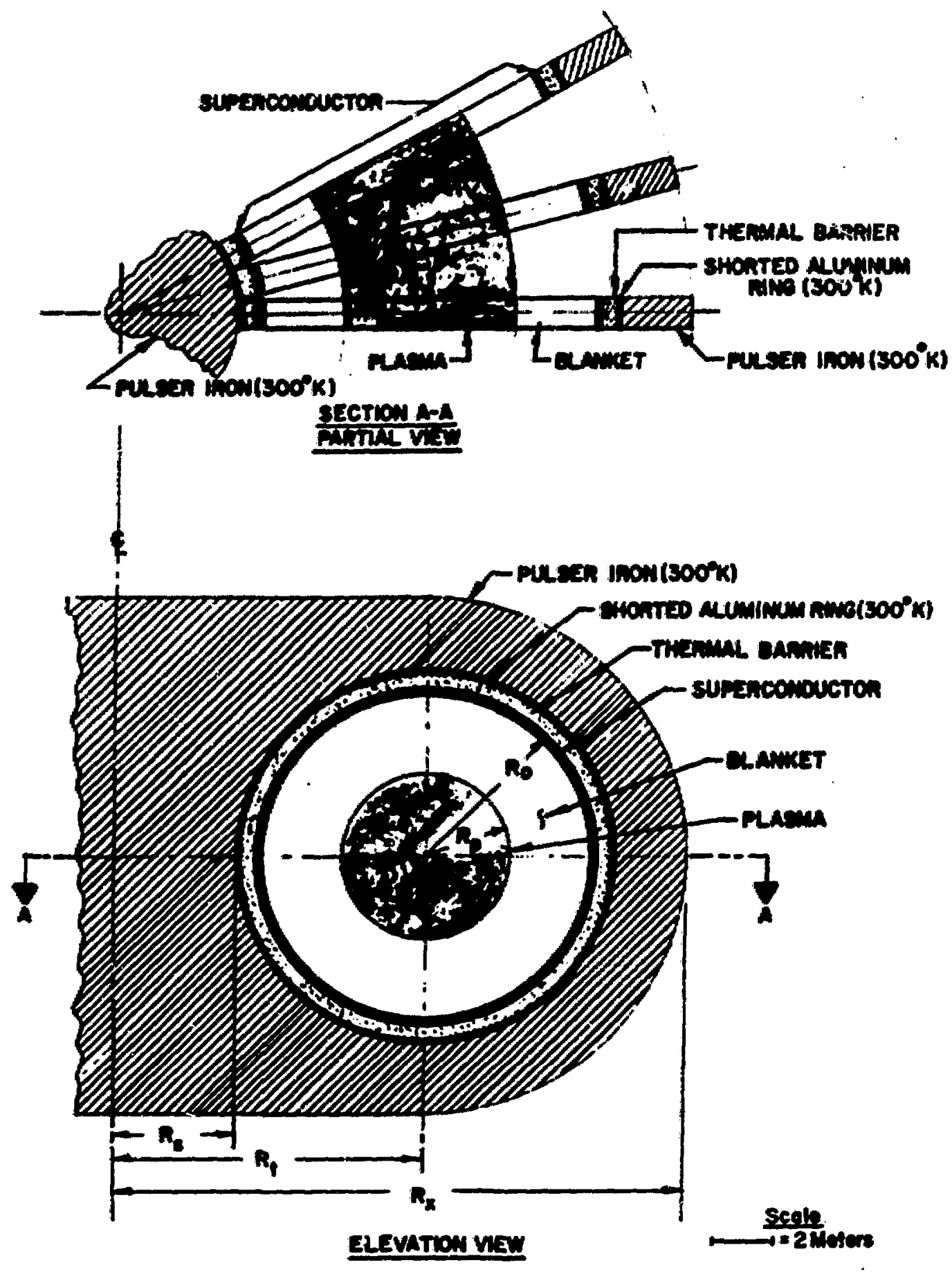

Figure 2 Illustration of warm reinforcement magnet coil for tokamak fusion reactor. 


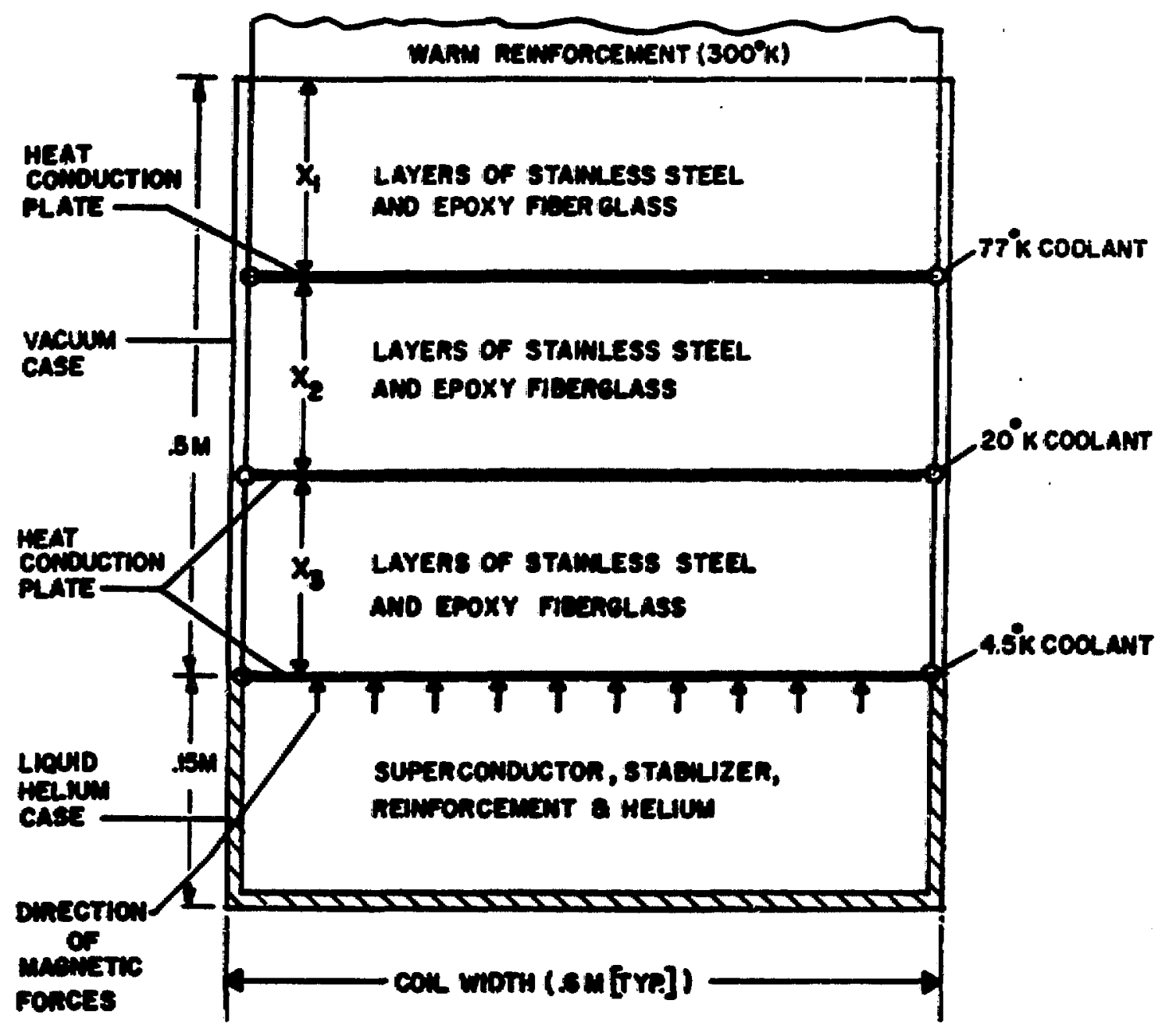

Figure 3 Illustration of thermal barrier concept. 


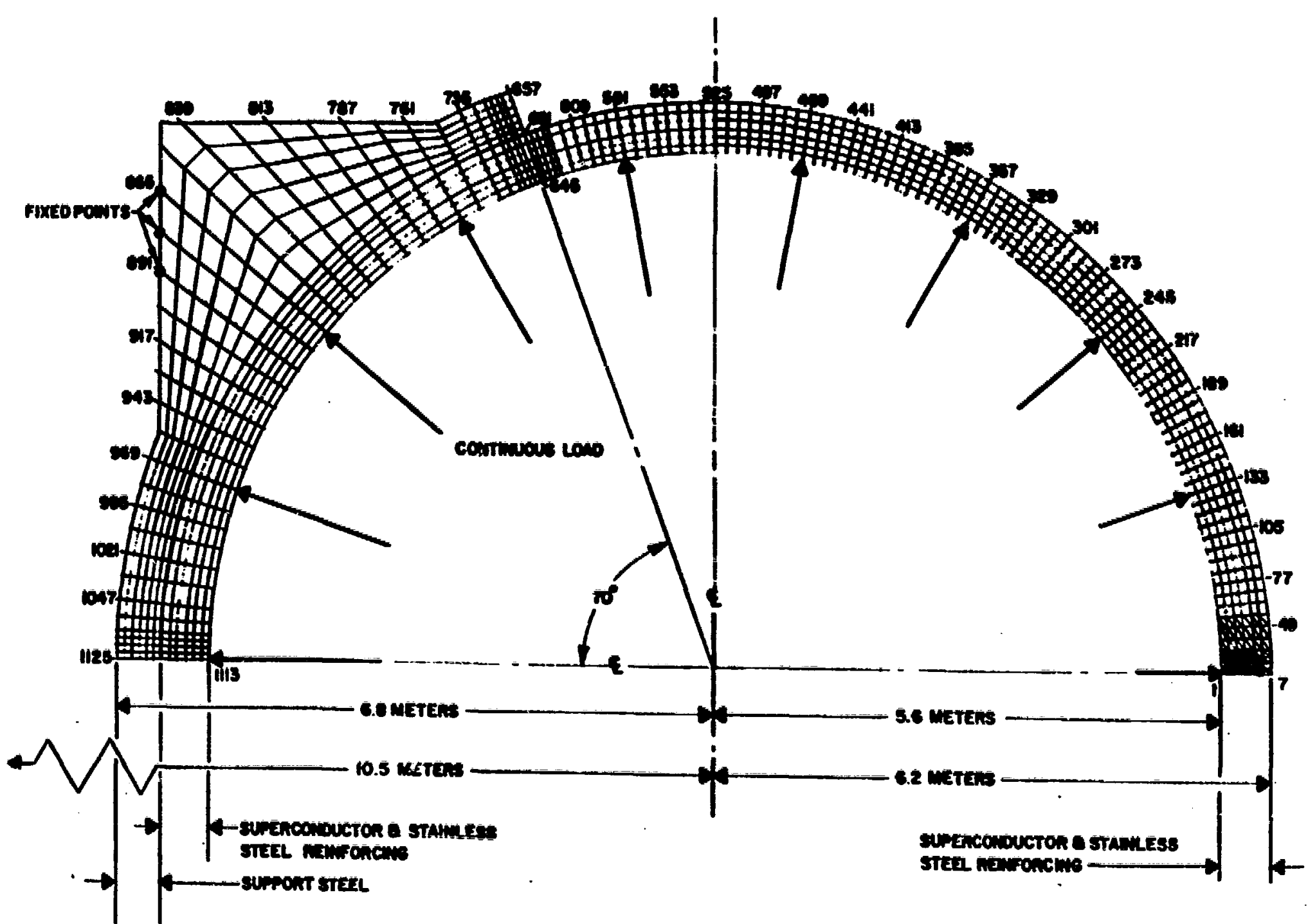

Figure 4 Finite element grid for 2-D stress ansiysis-cold reinforcement case. 


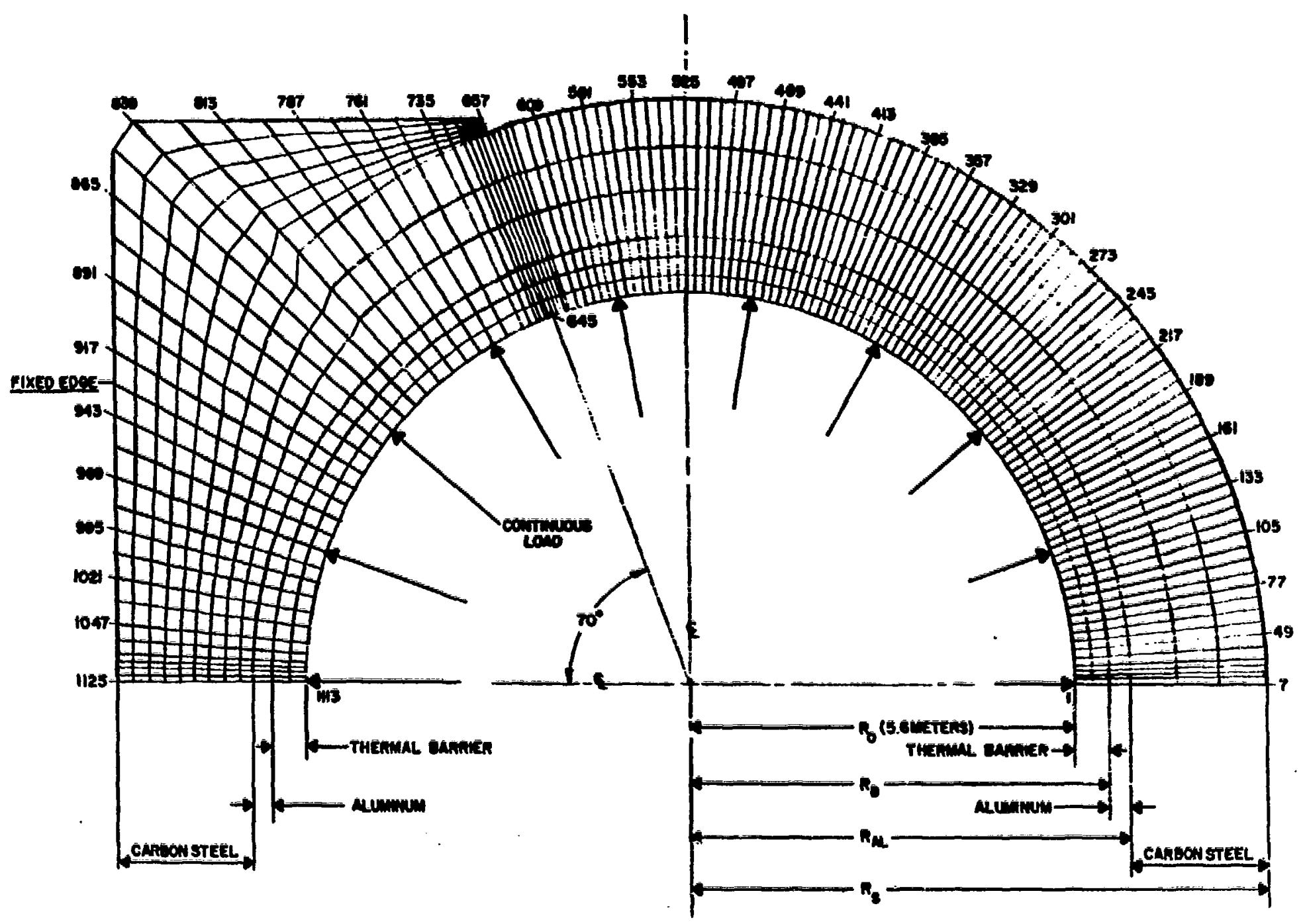

Figure 5 Finite element grid for 2-D stress analysis-warm re-

inforcement case. 


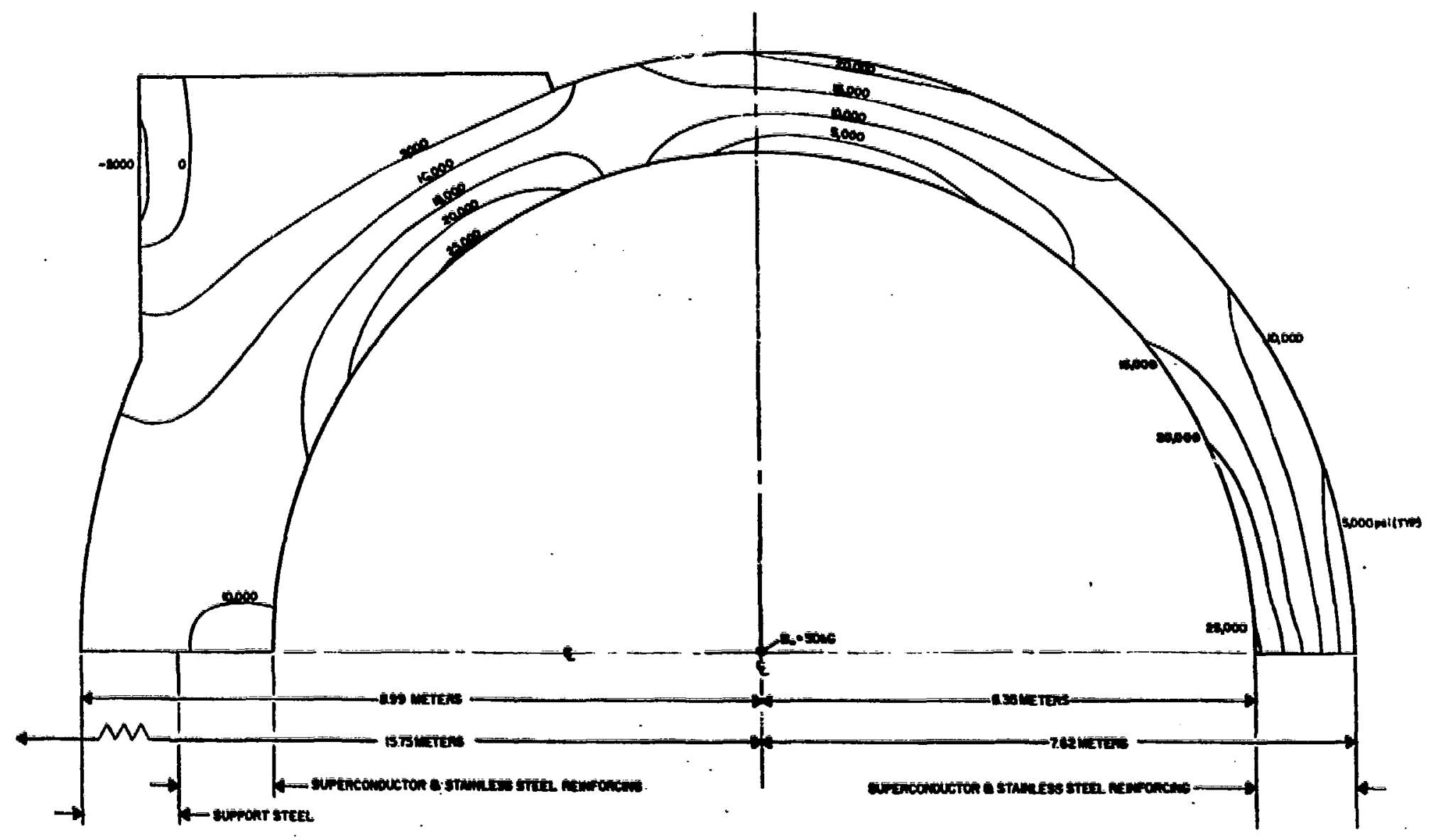

Figure 6 stress contours-cold reinforcement case. 


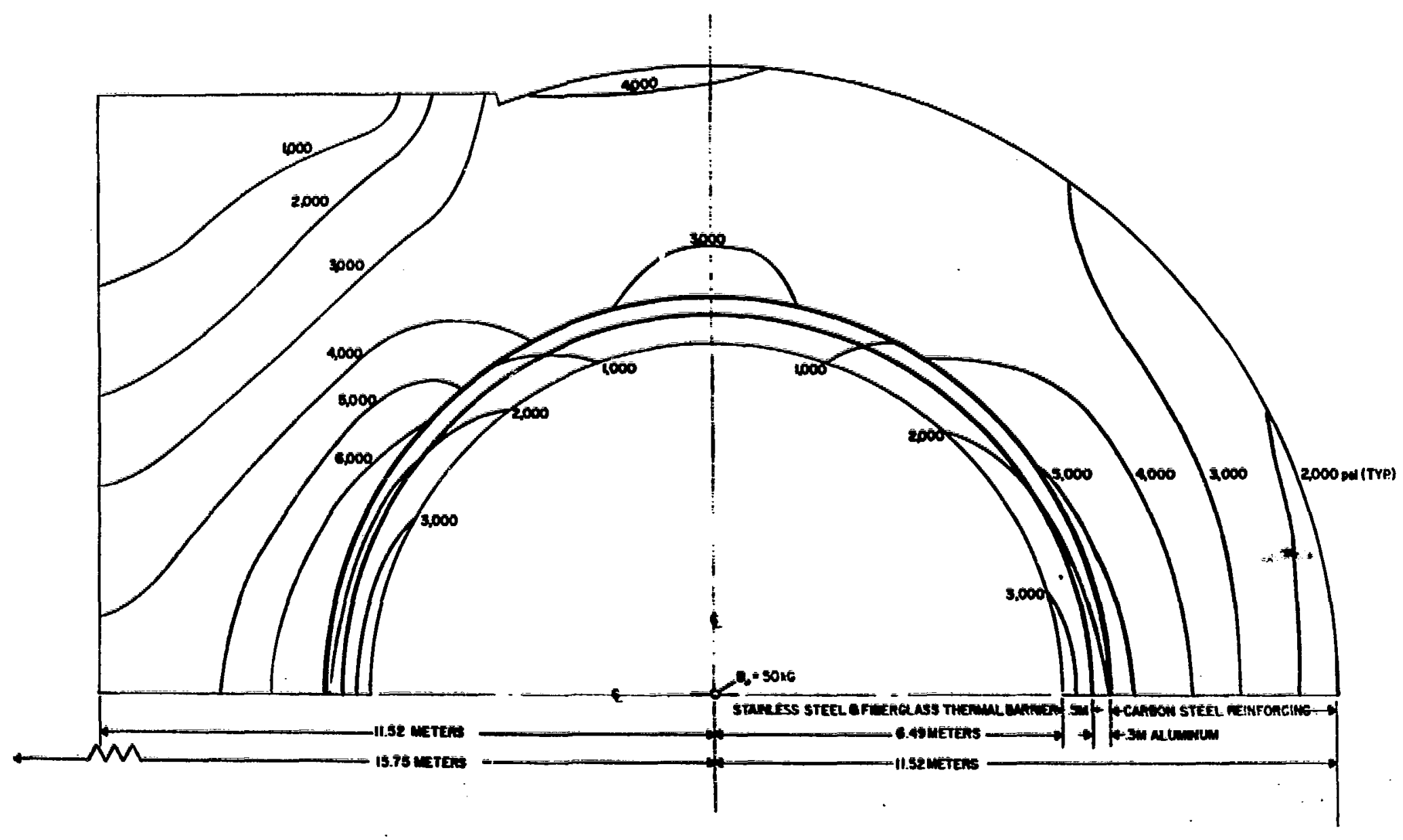

Figure 7 stress contours-warm reMEFWC XA4 inforcement case. 


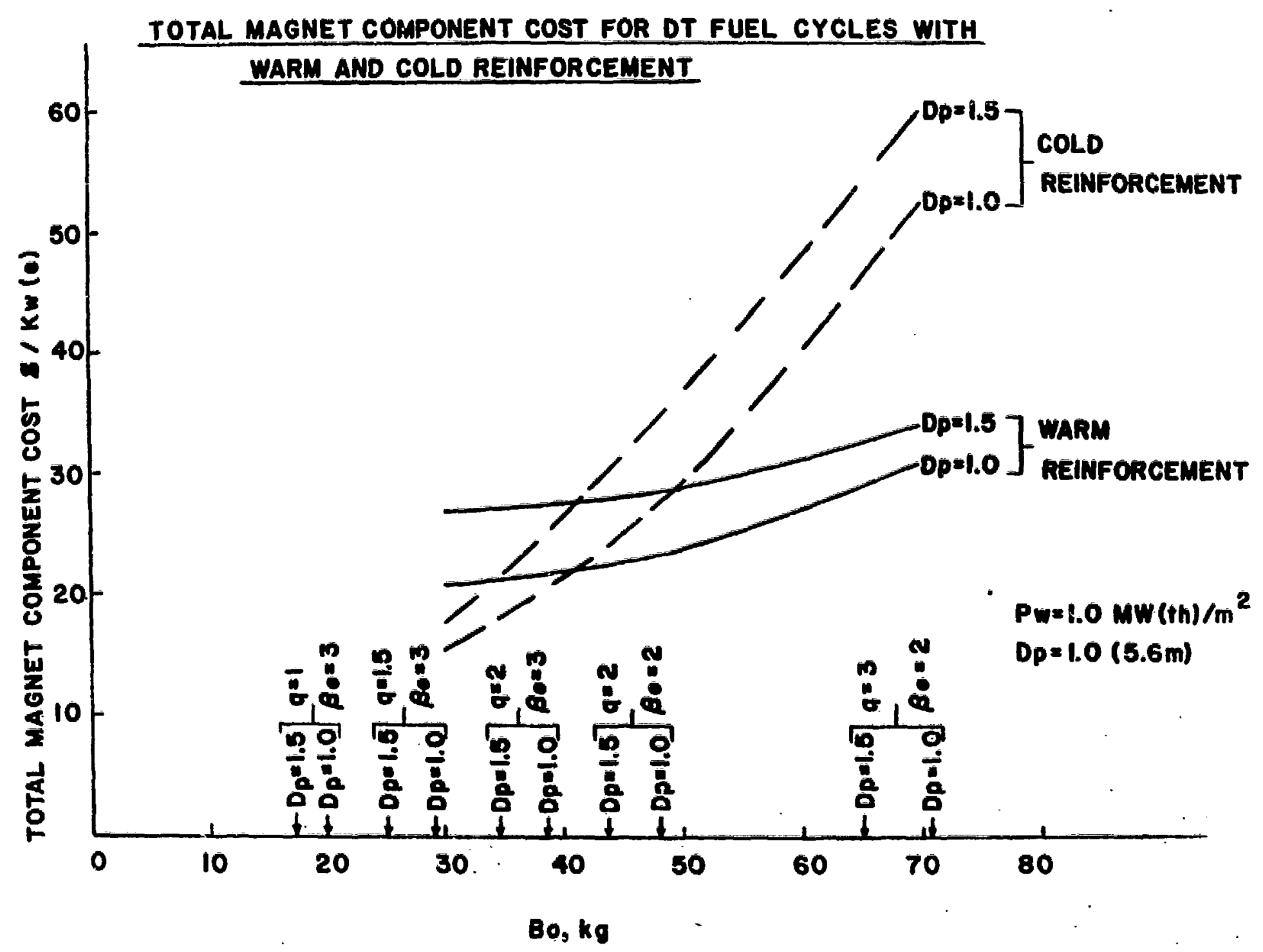

Figure 8 Magnet component cost versus on-axis magnetic field-DT fuel cycles. 


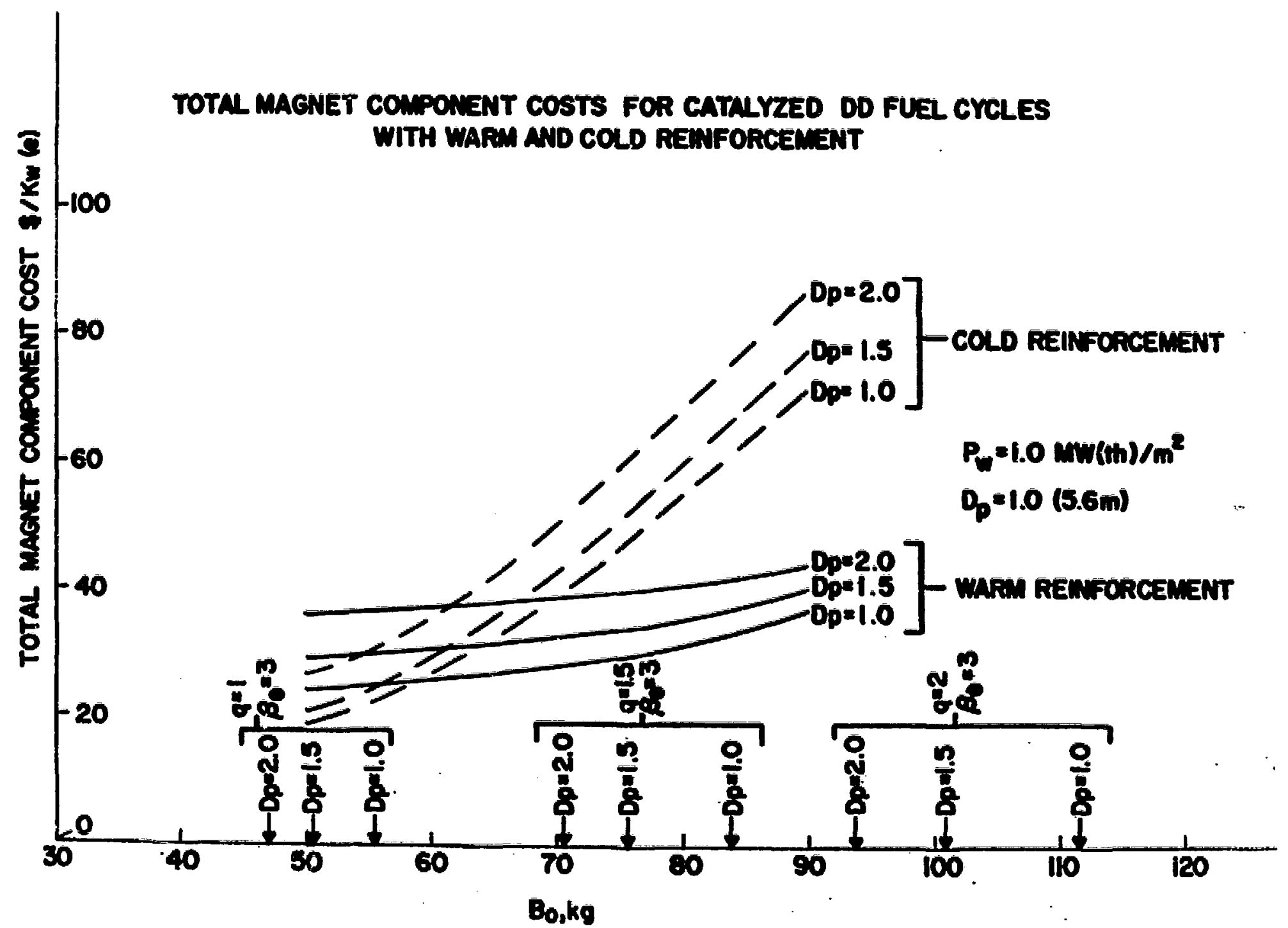

Figure 9 Magnet component cost versus on-axis magnetic field-DD fuel cycles. 